\title{
PENINGKATAN KOMPETENSI PENELITIAN TINDAKAN KELAS MELALUI METODE PELATIHAN, PENERAPAN DAN PENDAMPINGAN BAGI GURU SEKOLAH SATU ATAP WASUR DI KABUPATEN MERAUKE
}

\author{
Adi Sumarsono, Syamsudin \\ Jurusan Pendidikan Jasmani Kesehatan dan Rekreasi \\ Fakultas Keguruan dan Ilmu Pendidikan \\ Universitas Musamus \\ adi@unmus.ac.id
}

\begin{abstract}
The need for Classroom Action Research (CAR) must be carried out by a teacher in order to evaluate and find solutions to achieve effective learning. To support the research program for teachers, this community service was held. Through this service aims to increase the understanding, ability of a teacher's professional skills. The method in this service is through three stages of activity namely training, implementation and assistance. Each program is carried out sequentially by prioritizing the understanding of the teachers. This activity was carried out at Wasur One Roof Integrated High School in Merauke Regency. The training process is done through the activities of providing theoretical material in the classroom, the method of applying directly teaches writing on a computer using a lab. School computers and mentoring are carried out in a research revision process if the work proposal has been completed. The results of this dedication greatly provide additional and refreshing knowledge to the teachers, this is conveyed that there are still a lot of PTK material that teachers did not understand before the training was held. However, after participating in this activity, many ideas emerged and were able to create a class action research flow. Based on the pretest and posttest data there was a significant increase in teacher understanding. This community service activity was successfully organized by the support of the school as a partner
\end{abstract}

Keywords: training, implementation and assistance, CAR

\begin{abstract}
Abstrak
Kebutuhan Penelitian Tindakan Kelas (PTK) harus sudah di lakukan oleh seorang guru guna mengevaluasi dan mencari solusi guna mencapai pembelajaran yang efektif. Guna mendukung program penelitian bagi guru-guru, maka diselenggarakan kegiatan pengabdian ini. Melalui pengabdian ini bertujuan untuk menambah pemahaman, kemampuan keterampilan profesional seorang guru. Metode dalam pengabdian ini melalui tiga tahap kegiatan yaitu pelatihan, penerapan dan pendampingan. Masing-masing program dilaksnakan secara berurutan dengan mengedepankan pemahaman guru-guru. Kegiatan ini terlaksana di Sekolah Menengah Terintegrasi Satu Atap Wasur di Kabupaten Merauke. Proses pelatihan dilakukan melalui kegiatan pemberian materi teori didalam kelas, metode penerapan langsung aiajarkan menulis di komputer menggunakan lab. Komputer sekolah dan pendampingan dilakukan proses revisi penelitian jika proposal hasil kerja sudah selesai dikerjakan. Hasil dari pengabdian ini sangat memberikan tambahan dan penyegaran ilmu kepada guru-guru, hal ini disampaikan bahwa materi PTK masih banyak guru yang belum memahami sebelum diadakan pelatihan ini. Akan tetapi setelah mengikuti kegiatan ini banyak ide yang muncul dan sudah bisa membuat alur penelitian tindakan kelas. Berdasarkan data pretest dan postest terdapat peningkatan pemahaman guru yang signifikan. Kegiatan pengabdian ini sukses terselanggara dengan dukungan dari fihak sekolah sebagai mitra.
\end{abstract}

Kata Kunci: pelatihan, penerapan dan pendampingan, PTK. 


\section{PENDAHULUAN}

Keberhasilan dalam proses pembelajaran ditentukan dari banyak faktor. Diantaranya adalah kecenderungan guru yang mengajar secara profesional. Kemajuan pendidikan di Indonesia beragam keadaanya, demikuian pula keadaan keprofesionannya. Menurut pendapat pendapat (Widodo, Supardi, Suyoto, \& Wismanto, 2014) salah satu dari banyak masalah tentang rendahnya pendidikan di Indonesia adalah karena tingkat profesionalitas guru yang masih rendah. Keprofesionalan seorang guru dalam melaksanakan tugas selalu diikuti oleh kompetensinya.

Proses belajar mengajar antara siswa dan guru di sekolah selalu disampaikan dengan tujuan akhir adalah meningkatnya hasil belajar siswa. Guru yang profesional selalu melakukan perubahan seiring dengan keberhasilan yang di capai. Berbagai upaya yang dilakukan oleh seorang guru dalam melakukan perubahan diantaranya dengan selalu melakukan observasi dan refleksi dari kegiatan yang telah dilakukannya.

Proses mengajar guru kepada siswa dalam menyampaikan materi, tidaklah selalu berjalan dengan mudah karena penyampaian ilmu dan pengetahuan harus mencakup tiga ranah, baik pengetahuan, sikap dan keterampilan siswa. Karakteristik siswa yang berbeda-beda, serta keadaan pembelajaran yang tidak selalu stabil membuat peran guru harus lebih ektra dalam melakukan proses pembelajaran.
Untuk itulah guru yang profesional harus menguasai penelitian yang sistematis. Kompetensi profesional guru adalah kompetensi yang dilimiliki oleh guru tentang tugas melakukan penelitian tindakan kelas guna untuk memperbaiki proses belajar siswa (Sukonsih, 2011). Selain dari kompetensinya pendidikan yang berkualitas juga ditentukan oleh proses penyelenggaraanya. Kualitas pendidikan yang dikategorikan baik maupun buruk dapat diukur melalui proses yang diselenggarakan dalam pengelolaan pembelajarannya (Zulfadli \& Ferryansyah, 2017). Untuk itulah dalam setiap proses baik penyelenggara maupun tenaga pengajar wajib semua berlaku profesional.

Salah satu keprofesionalan seorang guru adalah dengan selalu membuat proses pembelajaran yang sesuai. Dalam mencapai hasil pembelajaran seroang guru wajib melalkukan instrospeksi diri melalui kegiatan penelitian yang terdokumentasi. Pelaksanaan kegiatan tersebut dapat melalui Penelitian Tindakan Kelas. Kompetensi profesional berkaitan dengan kompetensi keilmuan guru tentang penelitian dan publikasi karya ilmiah guru yang sudah diverivikasi, salah satunya berupa kewajiban guru melaksanakan penelitian untuk perbaikan kelas (Rahayu et al., 2012). Melalui kegiatan PTK diharapkan seorang guru lebih bersikap terbuka dalam proses pembelajaran.

Penelitian Tindakan Kelas mulai di gemari oleh guru sebagai aktivitas dalam meningkatkan kualitas profesionalisme 
guru. Setiap guru diwajibkan untuk meningkatkan kemampuan dalam profesinya serta mendokumentasikan dalam bentuk penelitian. Setiap kesulitan dan mampu dipecahkan melalui kegiatan pembelajaran dapat membantu keaktifan guru dalam meningkatkan kualitas dirinya secara profesionalisme. Guru modern adalah guru yang selalu tanggap dengan perubahan zaman yang seharusnya terbiasa mengembangkan profesioanlitasnya lewat menulis karya ilmiah (Ilfiandra, Suherman, Akhmad, \& Budiamin, 2016). Melalui Penelitian Tindakan Kelas diharapkan mampu membentuk sikap pembelajaaran yang terstruktur sesuai dengan dimensi keilmuan sesuai dengan jurusannya. Memalui kegiatan penelitian tindakan kelas dapat membuat guru mengembangkan kretaivitas dalam mengajar dan membuat perhitungan analisis mengapa dan atas dasar apa peningkatan pembelajaran dapat meningkat. Permasalahan yang dapat diatasi oleh guru melalui PTK dalam proses pembelajaran dapat melalui penerapan metode, model, strategi dan pendidikan dalam pembelajaran (Somatanaya, Herawati, \& Wahyuningsih, 2017).

Penilaian guru terhadap peningkatan kualitas pembelajaran sangat beragam. Kesulitan guru dalam penilaian terkadang menunjukkan permasalahan. Standar penilaian guru masih tergolong rendah hal ini dikarenakan pada saat yang hampir sama harus menilai sikap dan keterampilan siswa (Sumarsono, 2018). Oleh karena itu seorang guru wajib mampu melaksanakan proses dan menguasai proses. Seorang guru mempunyai tugas membimbing, mengajar dan mengarahkan dan mengevaluasi siswa (Wijayanti, Ariani, \& Triwarmiyati, 2019). Guru mempunyai faktor yang memberikan pemahaman strategis dalam menigkatkan mutu pendidikan di sekolah (Djulia, Simatupang, Nurhairani, \& Amrizal, 2017). Olah karena itu tugas seorang guru sangat dominan dalam memajukan hasil pembelajaran siswa.

Dukungan pemerintah juga sudah mulai didengungkan melalui kegiatan penelitian yang di wajibkan sebagai apresiaasi sertifikasi guru. Program sertifikasi dilakukan sebagai upaya peningkatan mutu pendidikan serta mutu kualitas profesiolisme guru. Pemerintah secara khusus setiap tahun memberikan dana bagi guru yang mampu merencanakan da melakukan penelitian tindakan kelas dengan baik (Depdiknas, 2008). Penelitian Tindakan Kelas menjadi semakin mendapatkan prioritas untuk bisa dilakukan guru, karena mempunyai beberapa manfaat. Menurut (Mediatati \& Ismanto, 2015), Pertama, PTK dilaksanakan secara terencana dan terkendali secara baik, akan meningkatkan kinerja guru dalam mengelola pembelajran yang berkualitas. Pelaksanaan PTK akan meningkatkan kompetensi guru, yang saat ini sedang menjadi isu utama dalam meningkatkan mutu pendidikan nasional. Kedua, menyelesaikan maslah kelas atau pembelajraan akan memberikan perbaikan pada kualitas pada proses pembelajaran. Ketiga, 
perbaikan peran guru dalam pembelajaran akan mampu memberikan konstribusi bagi peningkatan kualitas pendidikan secara nasional. Disamping itu laporan PTK juga bermanfaat baggi guru yang bersangkutan dalam hal kenaikan pangkat dan kredit pengembangan profesi keguruan.

Hal ini sesuai dengan peraturan bersama Mendiknas dan kepala BAKN No. 03/V/PB/2010 dan no.14 tahun 2010 tanggal 6 Mei 2010 yang mulai berlaku efektif pada tanggal 1 januari 2013 bahwa syarat kenaikan pangkat/jabatan guru dari IIIb kepangkat yang lebih tinggi wajib melaksanakan kegiatan pengembangan diri dan publikasi ilmiah yang antara lain dari hasil PTK. Pengertian tulisan ilmiah berdasarkan penyajian deskripsi, gagasan yang berdasarkan argumentasi bukti empirik dan kajian teori, dari hal yang disampaikan berdasarkan referensi yang dapat dirunut pada kebenaran empirik untuk mendukung pendapat tersebut (Siregar, 2011). Selaras dengan kebijakan sertifikasi guru, karya pengembangan profesi dalam bentuk PTK juga merupakan salah satu butir penting penentu keberhasilan guru dalam bentuk PTK juga merupakan aktuaslisasi guru dalam pembenahan mutu dan kualitas pembelajaran. Hal yang dapat dilakukan guru dalam meningkatkan hasil belajar siswa sangat beragam. Hal yang paling tepat dalam upaya peningkatan kualitas pembelajaran oleh guru adalah melalui PTK, hal ini dikarenakan sebagai pengajar dan pelaksana dari pembelajaran juga bertndak sebagai betul, hal ini akan memudahkan keinginan tujuan dari peningkatan hasil pembelajaran (Hunaepi et al., 2016).

Permasalahan dalam hal keprofesionalan guru dalam pembelajaran di Sekolah Terintegrasi Satu Atap Wasur adalah kompetensi guru yang masih rendah dalam peningkatan hasil. Proses belajar mengajar yang dilakukan masih terbatas dari pemberian materi dan transfer ilmu. Keprofeionalan guru membutuhkan bentuk penelitian ilmiah guna berbagai kebutuhan diantaranya syrat kenaikan pangkat. Untuk itu diperlukan update dan upgrade ilmu guna mencapai hal itu. Diantara cara yang dapat ditempuh adalah melalui kegiatan pelatihan. Model pelatihan yang intensif dilakukan dapat meningkatkan partisipasif guru dalam menyusun penelitian tindakan kelas (Mediatati \& Ismanto, 2015). Hal ini sesuai bahwa melalui kegiatan pengabdian.

\section{METODE PELAKSANAAN}

Metode yang telah dilakukan adalah hasil kesepakatan antara fihak pengabdi dan fihak mitra. Kegiatan pengabdian ini melibatkan tiga kegiatan yang berurutan sebagai langkah pelaksaan dilapangan. Tiga langkah meliputi Pelatihan, Penerapan dan Pendampingan. Ketiga langkah merupakan urutan baku yang pada masing-masing langkah sudah ditentukan pemateri dan luaran yang wajib di hasilkan oleh peserta kegiatan. Adapun lebih jelasnya kegiatan ini dapat digambarkan sebagai berikut: 


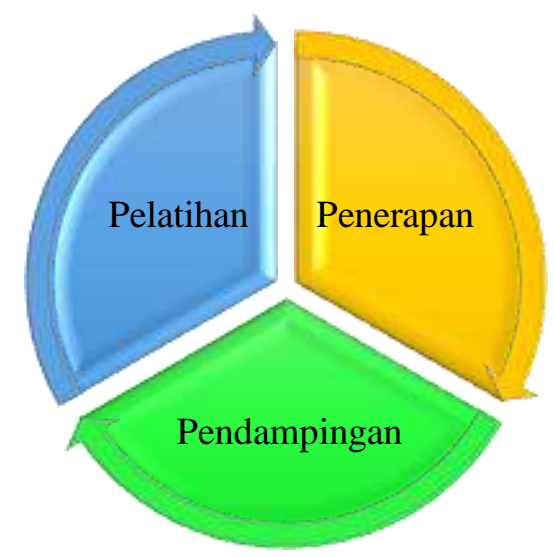

\section{Gambar 1. Rangkaian Metode Kegiatan Pengabdian}

Berdasarkan gambar diatas, penjelasan sesuai dengan langkah kegiatan ini adalah:

\section{A. Pelatihan}

Pelatihan partispasif yang dilakukan kepada peserta yaitu guru-guru dengan metode pemberian materi, mulai materi teori tentang Penelitian Tindakan Kelas, Implementasi dalam membuat yang diantaranya berisi panduan penulisan serta penulisan isi. Dalam proses pelatihan setiap guru diberikan materi dan selanjutnya diberikan tugas sesuai dengan materi tentang pemahaman mencari permasalahan yang sering dialami serta diangkat topik dalam judul Penelitian Tindakan Kelas. Selain materi tentang teori peserta juga diberikan materi tentang pencarian referensi baik buku maupun sumber dari jurnal di Internet.

B. Penerapan

Metode penerapan adalah penerapan implemantasi materi yang diberikan kepada Mitra dan dilanjutkan dengan diterapkan pada pembuatan proposal penelitian PTK. Peserta diajarkan tentang praktek pebuatan, pengetikan dan tata tulis dalam Penelitian Tindakan Kelas yang di sesuaikan dengan panduan Laporan Akhir PTK yang disusun oleh fihak sekolah.

C. Pendampingan

Setelah kemampuan guru sudah menguasai dan memahami materi yang sudah diberikan mulai dari awal sampai materi praktek. Langkah pada pendampingan, dilakukan dengan peserta melakukan pembuatan proposal PTK, sesuai dengan jalur dan mata pelajaran masing-masing guru. Keberadaan tim pengabdi pada posisi sebagai tutor dan mentor dalam mereview setiap hasil kerja guru.

\section{HASIL DAN PEMBAHASAN}

Kegiatan pengabdian ini dilakanakan selama lima hari pada bulan Agustus tahun 2019, adapun tempat pengabdian dilakukan di Sekolah 
Terintegrasi Satu Atap Wasur Kabupaten Merauke, sedangkan peserta adalah guru-guru sebanyak 18 Orang. Peserta pengabdian adalah guru tetap di sekolah dan rata-rata yang terkendala dengan kenaikan pangkat tentang syarat Penelitian Tindakan Kelas. Sebelum kegiatan dilaksanakan, peserta yang sudah siap menerma materi sebelumnya diberikan pretest dalam bentuk pengisian angket. Hal ini diberikan untuk mengukur keadaaan awal dan dampak perubahan yang ditimbulkan dari kegiatan ini. Kegiatan yang sudah dilaksanakan ini berdasarkan metode yang digunakan dalam pengabdian dapat dijelaskan sebagai berikut:

A. Pelatihan, dilakukan pada awal kegiatan dengan melibatkan tim pengabdi yang menjadi pemateri. Materi yang diberikan pada kegiatan awal adalah mengenal konsep PTK, tujuan dan kegunaan PTK serta langkah-langkah baku dalam Penelitian Tindakan Kelas. Materi yang diberikan dalam teori, supaya tidak hanya sebatas penyegaran ilmu peserta diberikan tugas untuk membuat dan menganalisa permasalahan yang dialami selama mengajar sesuai dengan mata pelajaran bidang studinya. Pada kegiatan pelatihan ini juga diberikan materi tentang solusi ataupun contoh-contoh yang dapat digunakan referensi sebagai solusi dalam mengatasi permasalahan selama pembelajaran. Contoh solusi yang diberikan dalam bentuk hasil Penelitian Tindakan kelas yang sudah dipublikasi. Kegiatan pelatihan yang telah dilakukan sesuai jadwal yang ditentukan ternyata melebihi waktu yang diestimasikan. Hasil review tentang pemahaman peserta serta konsultasi tanya jawab peserta yang banyak sesuai dengan mata pelajaran masing-masing guru.

B. Penerapan, kegiatan yang kedua sesuai dengan tahap pengabdian ini adalah penerapan ilmu dalam bentuk teori diimplementasikan dalam praktek. Kegiatan penerapan dilaksnakan dilaboratorium komputer sekolah. Seluruh peserta diarahkan unutk masing masing memindahkan hasil kerja pada hari sebelumnya pada komputer. Keadaan yang dijumpai pada kegiatan pengabdian ini adalah masih banyak peserta yang belum bisa dengan maksimal dalam melakukan pengetikan komputer. Kebanyakan peserta dari bapak dan ibu guru yang sudah umur senior merasa kesulitan kegiatan. Pemateri yang memberikan pengarahan pada kegiatan didepan memandu peserta dalam kegiatan tersebut. Materi yang disampaikan melalui tahap penerapan adalah memandu kegiatan pembuatan proposal PTK. Peserta dipandu dalam menulis judul, membuat pengetikan sesuai dengan sistematika penulisan proposal.

C. Pendampingan, Kegiatan selanjutnya adalah pendampingan yang dilaksanakan melalui pembuatan proposal yang sudah di ketik. Hasil dari pengetikan yang 
sudah dibuat selanjutnya di kirim ke panitia pengabdian dan diberikan review. Berdasarkan pendampingan masih banyak ditemukan kesalahan ketik dan tidak sesui dengan aturan penulisan. Pada sesi pendampingan suasana lebih cair karena para guru telah melakukan kegiatan dengan kesadaran. Dalam bentuk diskusi peserta kegiatan tidak malu-malu lagi menanyakan bagaimana cara pembuatan dan letak salah dan benarnya dari suatu tulisan.
Hasil pengabdian selain dari pemaparan hasil kegiatan pada akhir kegiatan ini dibagikan angket kepada peserta kegiatan dengan jenis dan bentuk pertanyaan sama pada awal kegiatan. Lembar posttest diberikan kepada para peserta dengan menambahkan pesan dan saran guna kebaikan perbaikan kegiatan kedepannya. Adapun hasil dari pengisian angket pretest dan posttets dapat dilihat sebagai berikut:

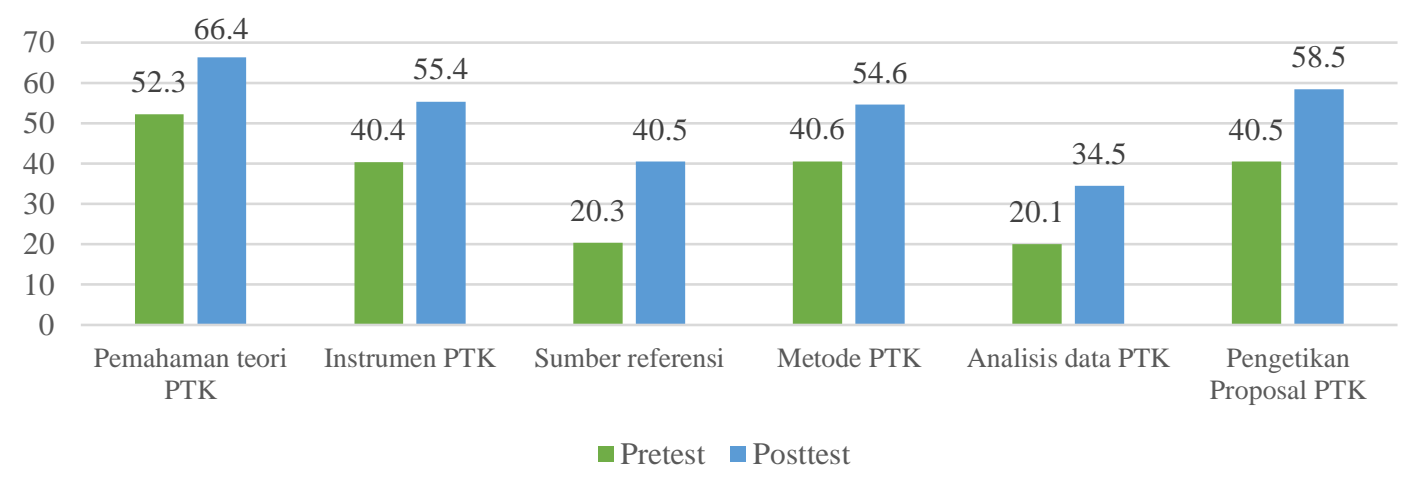

\section{Gambar 2. Grafik Perubahan Sebelum dan Sesudah Mengikuti Pengabdian}

Berdasarkan data pada diagram diatas, dapat dijabarkan bahwa guruguru sebelum mengikuti kegiatan dan setelah mengikuti kegiatan dapat dikatakan mengalami perubahan. Peningkatan tertinggi terjadi pada hal pemahaman tentang konsep teori Penelitian Tindakan Kelas sebesar $14,1 \%$. Berdasarkan pemaparan guruguru diketahui bahwa konsep PTK hanya sebatas pada teori bahwa penelitian sudah bisa dikira-kira keberhasilannya pada siklus ke dua serta pemahaman tentang pelaku dari PTK adalah guru yang bisa diwakilkan pada yang lebih faham. Hal ini sangat bertentangan dengan konsep yang telah dijelaskan bahwa PTK harus dilakukan guru bersangkutan dengan semangat memberikan stimulasi yang cocok dengan karakteristik dan budaya mengajar. Hal lain dari kegiatan ini menjelaskan bahwa perbedaan pelaskanaan pengabdian yang telah dilaksanakan dengan yang pernah sebelum-sebelumnya adalah pemberian materi yang langsung dipraktekkan melalui pendampingan pengetikan di komputer yang dilaskanakan di laboratorium komputer sekolah. adapun pencapaian peningkatan dari praktek langsung di komputer adalah sebesar 18 
\%. Pada kegiatan pengabdian ini guru masih banyak yang belum faham tentang instrumen, sumber referensi, metode Penelitian secara terstruktur serta analisis data. Pembuatan proposal PTK yang sudah dilaksanakan oleh guru-guru pada tahap akhirnya menghasilkan propsoal yang masih belum selesai. Dari proposal yang dihasilkan terdapat lima proposal dari lima orang guru yang sudah hampir selesai dan selalu aktif untuk konsultasi proposal.

Jumlah keseluruhan guru sebanyak delapan belas orang yang mengikuti kegiatan pengabdian ini pada tahap akhir kegiatan hanya lima orang guru yang dapat mengumpulkan proposal. Dari kegiatan ini dapat disarankan bahwa program pengabdian khususunya dengan menerapkan lima metode secara bersamaan akan terlihat jelas hasilnya. Akan tetapi untuk hasil maksimal hendaknya dipertimbangkan jumlah peserta dan jenis tagihan yang harus di kumpulkan pada akhir kegiatan.

\section{PENUTUP}

Proses kegiatan pengabdian kepada masyarakat telah dilaksanakan sesuai dengan tahap pengabdian. Pada proses yang telah dilakukan peserta kegiatan pengabdian mengikuti pelaksanaan dengan antusias. Kegiatan yang diikuti oleh guru mata pelajaran, menjalani melalui proses dengan mengedepankan pemahaman peserta. Pemateri yang memberikan materi pada kegiatan pengabdian diikuti dengan teori dan praktek. Hasil yang sudah dirasakan oleh peserta adalah perubahan pemahaman antara peserta kegiatan. Luaran yang sudah di hasilkan oleh peserta selain ilmu baru dalam pembuatan proposal juga didapatkan teknik dan jenis PTK yang dapat digunakan sebagai solusi perbaikan proses pembelajaran. Berdasarkan hasil pretest dan posttest yang didapatkan peningkatan yang signifikan. Kegiatan pengabdian berjalan sesuai rencana, walaupun masih belum menyentuh aspek hasil yang maksimal. Pembuatan propsoal penelitian Tindakan Kelas masih terkendala dengan materi yang masih belum difahami oleh guru. Hal ini dianggap wajar karena secara teknik pembelajaran metodologi penelitian tidak bisa diajarkan dalam waktu singkat. Sebagai perumpamaan mahasiswa semester akhir saja masih mengalami keulitan jika membuat proposal skripsi. Hal lain yang masih bisa difahami adalah para guru yang umurnya sudah tidak muda lagi masih bersemangat dalam menerima dan menyimpan informasi baru yang telah diberikan. Pada dasarnya konsep pengabdian yang diikuti oleh mitra dengan motivasi untuk kemajuan bersama akan menghasilkan hasil tercapainya hasil sesuai dengan kebutuhan.

Selain itu hasil pengabdian ini, didapatkan hasil dari pendapat peserta pengabdian bahwa ilmu yang didapatkan melalui kegiatan sangat bermanfaat. Berdasarkan penuturan peserta didapatkan informasi bahwa sebagian besar peserta mengenal PTK sejak kuliah. Ilmu itupun sudah jarang di laksanakan karena kegiatan mengajar yang padat. Ilmu yang sudah didapatkan selanjutnya akan digunakan untuk 
perbaikan proses pembelajaran untuk mendapatkan hasil yang diinginkan. Perbaikan proses pembelajaran di hasilkan mutu dan kualitas pada hasil belajar siswa.

\section{UCAPAN TERIMA KASIH}

Keterlaksanaan dari kegiatan pengabdian ini seluruhnya dukungan dana Universitas Musamus melalui pendanaan DIPA tahun 2019 Kegiatan pengabdian ini sesuai dengan Kontrak No. 262.24/UN52.8/PM/2019 Ucapan terima kasih di sampaikan kepada Rektor Universitas Musamus, melalui Lembaga Penelitian dan Pengabdian Masyarakat (LPPM).

\section{DAFTAR PUSTAKA}

Djulia, E., Simatupang, H., Nurhairani, \& Amrizal. (2017). IBM Penelitian Tindakan Kelas Guru SD Negeri 101868 dan SDN 105323 Desa Bakaran Batu Kabupaten Deli Serdang Melalui Pendampingan Pengembangan Keprofesian Berkelanjutan. Jurnal SEJ, 7(2), 182-190.

Hunaepi, Prayogi, S., Samsuri, T., Firdaus, L., Fitriani, H., \& Asy'ari, M. (2016). Pelatihan Penelitian Tindakan Kelas dan Teknik Penulisan Karya Ilmiah Bagi Guru. Lumbung Inovasi: Jurnal Pengabdian Kepada Masyarakat, I(1), 38-40.

Ilfiandra, Suherman, U., Akhmad, S. N., \& Budiamin, A. (2016). Pelatihan dan pendampingan penulisan karya tulis ilmiah bagi guru sd. Jurnal Pengabdian Pada masyarakat, 1(1), 70-81.

Mediatati, N., \& Ismanto, B. (2015). Peningkatan Kompetensi Menyusun Proposal Penelitian Tindakan Kelas Melalui Model Pelatihan Partisipatif dengan pendampingan Intensif bagi GuruGuru di SMP Negeri 2 Ampel. Prosiding Semiar Nasional Pendidikan Ekonomi \& Bisnis Fakultas Keguruan dan Ilmu Pendidikan, (November), 1-8.

Rahayu, M. H. S., Sukonsih, C. S., Harsan, T., Mustakim, Sudibyo, L., \& NS, P. (2012). Pelatihan Penulisan Proposal Penelitian Tindakan Kelas ( PTK) bagi Guruguru SD Negeri Kragilan Kec . Mojolaban. Seminar hasil Penelitian dan Pengabdian Kepada Masyarakat Tahun 2012 ISBN: $\quad$ 978-602-99172-7-7. Surakarta: LPPM Universitas Bantara.

Siregar, I. F. (2011). Pelatihan Pengembangan Laporna Hasil Penelitian Tindakan Kelas Menjad Artikel Ilmiah untuk Jurnal Bagi Guru-Guru Sekolah Dasar Kota Semarang dalam Upaya Meningkatkan Kompetensi Profesional. Jurnal ABDIMAS, 15(2), 121-130.

Somatanaya, A. A. G., Herawati, L., \& Wahyuningsih, S. (2017). Pelatihan Penelitian Tindakan Kelas (PTK) bagi Peningkatan Karier Guru-Guru Sekolah Dasar. Jurnal Siliwangi, 3(1), 169-175. 
Sukonsih, C. S. (2011). Pelatihan Pembuatan Proposal Penelitian Tindakan Tindakan Kelas ( PTK ) bagi Guru-Guru SDN Karangtalun I dan SDN Karangasem 2 Kecamatan Tanon Kabupaten Sragen. Seminar hasil Penelitian dan Pengabdian Kepada Masyarakat Tahun 2011 ISBN: 978-602-99172-5-3, 16. Surakarta: LPPM. universitas Bantara Sukoharjo.

Sumarsono, A. (2018). Persepsi Guru Madrasah Ibtidaiyah (MI) dalam Menerapkan Kurikulum 2013 di Kabupaten Merauke. Al-Islah, 10(2), 156-170.

Widodo, S., Supardi, Suyoto, \& Wismanto, A. (2014). Peningkatan Kompetensi Guru Profesional Berbasis Penulisan Artikel Hasil PTK bagi Guru Anggota PGRI di
Kabupaten Purworejo. Seminar nasional hasil Pengabdian Lembaga Penelitian dan Pengabdian Kepada Masyarakat, 101-107.

Wijayanti, S. H., Ariani, Y. D., \& Triwarmiyati, M. (2019). Penguatan Kompetensi Guru Sekolah Dasar Negeri Di Kecamatan Cisauk Melalui Pelatihan Penelitian Tindakan Kelas. Kaji Tindak: Jurnal Pemberdayaan Masyarakat, 3(1), 55-62.

Zulfadli, \& Ferryansyah. (2017). Pelatihan dan Bimbingan Pembuatan Karya Tulis Ilmiah Berbasis Penelitian Tindakan Kelas (PTK) di SD Muhammadiyah 1 Tarakan. Jurnal Pengabdian Mayarakat Borneo, 1(1), 40-43. 